The constant-solvent phase diagram is shown in Fig. 2. Three breaks are seen, as expected of a threecomponent system. Precipitation was visible at haemoglobin concentrations above the first break. The precipitate was examined microscopically in some experiments at a magnification of 600 and did not appear to be crystalline.

\section{DISCUSSION}

Our results are similar to the ammonium sulphate solubility curves obtained with horse carboxyhaemoglobin by Roche et al. (1954). Three breaks in the precpitation curve have been found, the position of all being dependent upon the concentration of protein originally in solution. There was no evidence of crystallization, and it is concluded that normal adult human carboxyhaemoglobin comprises three molecular species.

Kunkel \& Wallenius (1955) submitted normal adult human carboxyhaemoglobin to electrophoresis in starch slabs and obtained three components. The eluted components all had the same absorption spectra as the original pigment, and when they were submitted to electrophoresis separately they retained the mobility shown in the first experiment. It is therefore unlikely that these components represent denaturation products, or different forms of a single chemical substance. Morrison \& Cook (1955) were also able to obtain three components from normal adult oxyhaemoglobin by chromatography on a column of Amberlite IRC-50 ion-exchange resin. The spectra of the components were found to be normal, from which it was concluded that no significant denaturation had taken place.

The discontinuities in the precipitation curve at high concentrations of phosphate reported by Roche et al. $(1953 a, b)$ and attributed by them to the presence of three small foetal haemoglobin components in the haemoglobin of normal adults, were not observed in our experiments. It was not possible in our tests to obtain very high salt concentrations without modifying the conditions, so that we have not excluded the possibility that other breaks occur in this region. However, other results, including accurate measurements of the rate of denaturation of haemoglobin in alkali (Beaven, Ellis \& White, 1956), suggest that the proportion of foetal haemoglobin in the blood of normal adults is less than $1 \%$ of the total, if any is present at all.

\section{SUMMARY}

The results of variable-solvent and variable-solute tests indicate that normal adult human carboxyhaemoglobin contains three distinct molecular species, thus confirming the heterogeneity observed by Kunkel \& Wallenius by electrophoresis and by Morrison \& Cook by chromatography on ionexchange resin columns.

The authors are indebted to Drs A. G. Ogston and R. Cecil for their criticism of the manuscript.

\section{REFERENCES}

Beaven, G. H., Ellis, M. \& White, J. C. (1956). Nature, Lond., 178, 857.

Cohn, E. J. (1925). Physiol. Rev. 5, 349.

Huisman, T. H. J. \& Prins, H. K. (1955). J. Lab. clin. Med. 46, 255.

Itano, H. A. (1956). Annu. Rev. Biochem. 25, 331.

Kunkel, H. G. \& Wallenius, G. (1955). Science, 122, 288.

Morrison, M. \& Cook, J. L. (1955). Science, 122, 920.

Northrop, J. H. \& Kunitz, M. (1930). J. gen. Physiol. 13, 781.

Ogston, A. G. \& Tombs, M. P. (1956). Nature, Lond., 178, 200.

Roche, J. \& Derrien, Y. (1953). Sang, 24, 97.

Roche, J., Derrien, Y., Reynaud, T., Laurent, G. \& Roques, M. (1954). Bull. Soc. Chim. biol., Paris, 35, 51.

Roche, J., Derrien, Y. \& Roques, M. (1953a). C.R. Soc. Biol., Paris, 146, 689.

Roche, J., Derrien, Y. \& Roques, M. (1953b). Bull. Soc. Chim. biol., Paris, 35, 933.

Smithies, O. (1954). Biochem. J. 58, 31.

\title{
Determination of Creatine in Biological Fluids
}

\author{
By D. R. ANDERSON, C. M. WILliaMS, G. M. KRISE ANd R. M. DOWBEN* \\ The Radiobiological Laboratory, Balcones Research Center, Austin, Texas, and the \\ Department of Radiobiology, School of Aviation Medicine, Randolph Field, Texas
}

(Received 25 January 1957)

The colour reaction between diacetyl and creatine in the presence of $\alpha$-naphthol can be used for the determination of creatine (Barritt, 1936). A number of inhibitory substances occur in urine, plasma and tissue extracts which interfere with the formation of

* Present address: Department of Medicine, Northwestern University, Chicago 11, Illinois, U.S.A. the coloured product (Eggleton, Elsden \& Gough, 1943). It was shown by Ennor \& Stocken (1948) that sulphydryl compounds could produce marked inhibition of the diacetyl reaction and that the interference could be prevented by the addition of $p$-chloromercuribenzoic acid. On applying their method to urine, Ennor \& Stocken (1953) found that 
other unknown urinary constituents also hindered the diacetyl reaction. They reported that the interference could be overcome in part by increasing the concentration of $\alpha$-naphthol.

In determinations of creatine in rat urine according to the directions of Ennor \& Stocken (1953), adequate recovery of added creatine was not obtained. The addition of $p$-chloromercuribenzoic acid did not improve the results. An attempt then was made to separate the inhibitors of the diacetyl reaction from creatine by means of ion-exchange chromatography. It was found that creatine is not readily absorbed on either strong anion or weak cation exchangers. Provided the concentration of other cations is not high, it is absorbed, however, on a strong cation-exchange resin, from which it may be then eluted with sodium acetate. No interference in the diacetyl reaction was observed after the separation of the creatine by chromatography.

\section{EXPERIMENTAL}

\section{Reagents}

Creatine. Reagent-grade creatine (Nutritional Biochemicals Corp., Cleveland, Ohio, U.S.A.) was recrystallized twice from hot water and dried over $\mathrm{CaCl}_{2}$. The water of crystallization was driven off by heating at $120^{\circ}$. Paper chromatograms on Whatman no. 1 paper with the solvents in Table 3 gave a single spot with the diacetyl test at the $R_{\mu}$ corresponding to creatine and no spot with the Jaffe test at the $\boldsymbol{R}_{\boldsymbol{F}}$ corresponding to creatinine (Found: N, 31.9. Calc. for $\mathrm{C}_{4} \mathrm{H}_{9} \mathrm{O}_{2} \mathrm{~N}_{3}: \mathrm{N}, 32 \cdot 0 \%$ ).

Stock alkali. Sodium hydroxide $\left(60 \mathrm{~g}\right.$.) and $\mathrm{Na}_{2} \mathrm{CO}_{3}$ $(160 \mathrm{~g}$.) in 11 . of water was used.

Diacetyl. Diacetyl (Nutritional Biochemicals Corp.) was purified by distillation in $100 \mathrm{ml}$. batches; all but the first and last $10 \mathrm{ml}$. portions of the fraction distilling at $88^{\circ}$ was used. A $1 \%$ stock solution in water was diluted 1:20 immediately before use.

$\alpha$-Naphthol. The commercial reagent was recrystallized from $0.01 \mathrm{~N}-\mathrm{HCl}$. The purified $\alpha$-naphthol can be stored in a desiccator in the dark for several months. A $1 \cdot 6$ or $3.2 \%$ solution in stock alkali is prepared immediately before use.

Ion-exchange resins. Amberlite IRA-401 (strong anion exchanger), Amberlite IRC-50 (weak cation exchanger), and Amberlite IR-120 (strong cation exchanger) were obtained from Rohm \& Haas Co. (Philadelphia, Pa., U.S.A.) as porous beads (30-60 mesh). The anion exchanger was converted into the hydroxide cycle by immersion in $0 \cdot 1 \mathrm{~N} \cdot \mathrm{NaOH}$. The cation exchangers were converted into the hydrogen cycle with $0 \cdot 1 \mathrm{~N}-\mathrm{HCl}$. All resins were then washed with water until the effluent was neutral.

Cellulose. Whatman powdered cellulose was used.

Solvents. Reagent-grade solvents [Eastman Kodak Co. (Rochester, N.Y., U.S.A.) or Matheson Co. Inc. (Norwood, Ohio, U.S.A.)] were used without further purification. 2-Picoline obtained from two different sources gave somewhat different $R_{F}$ values; for this reason, when 2-picoline is used in a developer, the $R_{F}$ values should be determined for each batch.
Creatinine. A stock solution containing $1 \mathrm{mg} . / \mathrm{ml}$. in $0 \cdot 1 \mathrm{~N}-\mathrm{HCl}$ was obtained from Hartman-Leddon Co. Inc. (Philadelphia, Pa., U.S.A.).

Guanidinoacetic acid and arginine. Guanidinoacetic acid (Found: N, 35.9. Calc. for $\mathrm{C}_{3} \mathrm{H}_{7} \mathrm{O}_{2} \mathrm{~N}_{3}: \mathrm{N}, 35.9 \%$ ) and arginine (Found: $\mathrm{N}, 32 \cdot 1$. Calc. for $\mathrm{C}_{6} \mathrm{H}_{14} \mathrm{O}_{2} \mathrm{~N}_{4}: \mathrm{N}, 32 \cdot 2 \%$ ) (Nutritional Biochemicals Corp.) gave single spots on paper chromatograms (Table 1).

p-Chloromercuribenzoic acid. Reagent-grade $p$-chloromercuribenzoic acid (142 mg.) (K \& K Laboratories, Long Island City, New York, U.S.A.) was dissolved in the minimum amount of $\mathrm{N}-\mathrm{NaOH}$ and diluted to $100 \mathrm{ml}$. with water.

\section{Determination of creatine in urine}

A sample (approx. $3 \mathrm{ml}$.) of urine containing not more than 3-4 mg. of creatinine is diluted $1: 5$ and passed through four consecutive columns $(7 \mathrm{~mm}$. diameter) containing 10-15 mm. of cellulose, $200 \mathrm{~mm}$. of Amberlite IRA-401, $200 \mathrm{~mm}$. of Amberlite IRC-50, and $200 \mathrm{~mm}$. of Amberlite IR-120 respectively. The columns are mounted at successively lower levels in a rack. The lower end of each tube is plugged with a plastic adapter and an 18-gauge hypodermic needle which is fitted with a polythene tube leading to the next column. The last tube is fitted with an adapter and adjustable valve to regulate the outflow. The outflow is adjusted to equal the inflow (about 15-20 drops/min.). The other columns are arranged so that the hydrostatic pressure and siphoning action give continuous flow of added liquid without any column running dry. After the urine has been added, the column train is washed with about $200 \mathrm{ml}$. of water. Creatine is eluted from the Amberlite IR-120 column with sufficient $\mathrm{N}$-sodium acetate to make $50 \mathrm{ml}$. of eluate.

A $7 \mathrm{ml}$. portion (containing $10-40 \mu \mathrm{g}$. of creatine) is mixed with $2 \mathrm{ml}$. of $1.6 \% \alpha$-naphthol and $1 \mathrm{ml}$. of $0.05 \%$ diacetyl is added with gentle swirling. The optical density is measured at $525 \mathrm{~m} \mu$ after $20 \mathrm{~min}$. but before $30 \mathrm{~min}$. The coloured product is stable until $30 \mathrm{~min}$. (Ennor \& Stocken, 1953) and then diminishes somewhat in intensity during the next hour.

The resin columns may be regenerated and used for eight to ten runs before replacement with new resins is necessary.

\section{Determination of creatine in plasma and tissue extracts}

Plasma or tissue extract (3-6 ml.) is added to a $50 \mathrm{ml}$. flask containing $3 \mathrm{ml}$. of Amberlite IRA-401 and $3 \mathrm{ml}$. of Amberlite IRC-50, and the volume is brought to $25 \mathrm{ml}$. with water. The flask is shaken for $1 \mathrm{hr}$. at room temp. The contents are filtered, the residue is washed with $200-300 \mathrm{ml}$. of water. Filtrate and washings are run through a column $(7 \mathrm{~mm} . \times 70 \mathrm{~mm}$.) of Amberlite IR-120. Creatine is eluted from the column with $\mathrm{N}$-sodium acetate to volume in a $25 \mathrm{ml}$. volumetric flask. In plasma, a small amount of protein, which interferes with the colorimetric determination, is eluted with the creatine. This residual protein is removed by adding $1 \mathrm{ml}$. of stock alkali to $7 \mathrm{ml}$. of eluate. The precipitate is removed by centrifuging after $15 \mathrm{~min}$. To the supernatant, $1 \mathrm{ml}$. of $3 \cdot 2 \% \alpha$-naphthol and $1 \mathrm{ml}$. of diacetyl solution are added. The optical density is measured ut $525 \mathrm{~m} \mu$ at $20 \mathrm{~min}$. 
Table 1. $R_{F}$ values for creatine, creatinine, arginine, and guanidinoacetic acid The ascending method with Whatman no. 1 paper was used. Time of run: $18 \mathrm{hr}$. at $25^{\circ}$.

\begin{tabular}{lcccc}
\multicolumn{1}{c}{ Solvent } & Creatinine & Creatine & Arginine & $\begin{array}{c}\text { Guanidinoacetic } \\
\text { acid }\end{array}$ \\
2-Picoline-water (9:1, v/v) & 0.31 & 0.03 & 0.01 & 0.03 \\
Acetone-30\% acetic acid (6:4, v/v) & 0.74 & 0.59 & 0.43 & 0.59 \\
$\begin{array}{l}\text { 2-Picoline-aq. } \mathrm{NH}_{3} \text { soln. (sp.gr. 0.88)-water } \\
\text { (6:2:1, by vol.) }\end{array}$ & 0.62 & 0.32 & 0.20 & 0.34 \\
$\begin{array}{c}\text { Pyridine-aq. } \mathrm{NH}_{3} \text { soln. (sp.gr. 0.88)-water } \\
\text { (6:2:1, by vol.) }\end{array}$ & 0.84 & 0.61 & 0.47 & 0.65 \\
$\begin{array}{l}\text { Dimethylformamide-aq. } \mathrm{NH}_{3} \text { soln. (sp.gr. 0.88)- } \\
\text { water (6:2:1, by vol.) }\end{array}$ & 0.78 & 0.43 & 0.31 & 0.41
\end{tabular}

\section{Paper-chromatographic separation of creatine and creatinine}

Milligram samples of pure creatine and creatinine may be separated on paper, for example, for assay of specific radioactivity. Urine (100-200 ml.) is first desalted by running it through successive columns of cellulose, Amberlite IRA-401 and Amberlite IRC-50. The volume of the eluate is reduced to $10 \mathrm{ml}$. with a stream of air. The concentrated solution is stripped on 18 in. $\times 22$ in. sheets of Whatman no. 1 paper mounted on a drum which rotates (Yanofsky, Wasserman \& Bonner, 1950). The chromatograms are developed by ascending chromatography with the solvents listed in Table 1 for $12-18 \mathrm{hr}$. at $25^{\circ}$. Test strips are cut from the edges of the large sheet.

Creatine is detected by dipping the strips into each of the following solutions in succession: (1) methanol, (2) $6 \%$ (w/v) $\mathrm{NaOH}$ in methanol, (3) $400 \mathrm{mg}$. of $\alpha$-naphthol and $3 \mathrm{~g}$. of $\mathrm{NaOH}$ in $25 \mathrm{ml}$. of methanol, and (4) diacetyl solution (stock diacetyl solution diluted 1:10 with methanol). Creatine gives a red band at room temp. after 5-10 min. This test gives the most intense colour with creatine, but arginine and guanidinoacetic acid give positive, albeit less strong, reactions.

For the detection of creatinine the strip is dipped into a mixture of $15 \mathrm{ml}$. of $1.2 \%$ picric acid in methanol and $5 \mathrm{ml}$. of $6 \% \mathrm{NaOH}$ in methanol, blotted lightly and allowed to dry. After a few min. at room temp. an orange band characteristic of creatinine appears against the yellow background.

Arginine and guanidinoacetic acid were located by means of an alkaline sodium nitroprusside-potassium ferricyanide spray (Berry, Sutton, Cain \& Berry, 1951). Arginine may be identified in the presence of creatine and guanidinoacetic acid by use of ninhydrin in butanol.

\section{RESULTS}

In the methods described, the cellulose is used to remove colloidal and particulate matter. In the method for urine the electrolytes are largely removed by the first two resin columns. The Amberlite IRC-50 column absorbs $95-100 \%$ of the arginine present in amount up to $1 \mathrm{mg}$. and $96-100 \%$ of the creatinine present in amounts up to $4.5 \mathrm{mg}$. (Table 2). Guanidinoacetic acid is absorbed by the Amberlite IR-120 column and eluted by the sodium acetate along with the creatine. The observed

\section{Table 2. Removal of creatinine from urine by IRC-50 ion-exchange resin}

Urine was passed through a $200 \mathrm{~mm}$. column $(7 \mathrm{~mm}$. diam.) of Amberlite IRA-401 and then through a $200 \mathrm{~mm}$. column of Amberlite IRC-50. Creatinine in the effluent was determined by the method of Owen, Iggo, Scandrett \& Stewart (1954).

$\begin{array}{cccc}\begin{array}{c}\text { Creatinine } \\ \text { in original } \\ \text { sample } \\ \text { Urine }\end{array} & \begin{array}{c}\text { Creatinine } \\ \text { in effluent } \\ \text { from IRC-50 } \\ \text { column } \\ (\mu \mathrm{gl})\end{array} & \begin{array}{c}\text { Amount } \\ \text { absorbed on } \\ \text { IRC-50 } \\ \text { column } \\ 1\end{array} & \begin{array}{c}(\mu \mathrm{g} .) \\ (\%)\end{array} \\ 1 & 1210 & 45 & 96.5 \\ 2 & 1400 & 0 & 100 \cdot 0 \\ 3 & 2200 & 30 & 98 \cdot 5 \\ 3 & 4080 & 105 & 97 \cdot 5 \\ & 4400 & 137 & 97 \cdot 0\end{array}$

value of creatine with the diacetyl colour test is about $11-13 \%$ high when guanidinoacetic acid and creatine are present in equal quantity in urine. Recoveries of known amounts of creatine added to several urine specimens in concentrations up to $1 \mathrm{mg} . / \mathrm{ml}$. ranged between 95.0 and $98.5 \%$.

Attempts were made to obtain higher readings from the eluted samples by counteracting possible interference from sulphydryl compounds with $p$ chloromercuribenzoic acid. Values for creatine with and without $p$-chloromercuribenzoic acid were found to be the same.

When it was necessary to wait longer than 1-2 hr. for analysis, samples were preserved by freezing. At $-10^{\circ}$, no change in creatine concentration occurs over a period of several weeks. The mean value of creatine excretion for eight normal men was $48 \cdot 4 \pm 26 \cdot 2 \mathrm{mg}$. $/ 24 \mathrm{hr}$.

Several other methods for the deproteinization of plasma and tissue extracts were found unsatisfactory. Protein-free filtrates obtained with use of trichloroacetic acid were not suitable because $\alpha$-naphthol reacts with trichloroacetic acid in light to form a blue substance (Eggleton et al. 1943). Methods which employ strong acids cause the conversion of creatine into creatinine, and strong bases cause the conversion of creatinine into creatine. Paper chromatography of plasma before 
Table 3. Recovery of creatine added to $3 \mathrm{ml}$. of rat plasma

\begin{tabular}{cccc}
$\begin{array}{c}\text { Creatine } \\
\text { (added) } \\
(\mu \mathrm{g} .)\end{array}$ & $\begin{array}{c}\text { Total } \\
\text { creatine } \\
\text { (calc.) } \\
(\mu \mathrm{g} .)\end{array}$ & $\begin{array}{c}\text { Creatine } \\
\text { (found) } \\
(\mu \mathrm{g} .)\end{array}$ & $\begin{array}{c}\text { Recovery } \\
(\%)\end{array}$ \\
0 & - & $52 \cdot 8$ & - \\
20 & $72 \cdot 8$ & $72 \cdot 0$ & 96 \\
20 & $72 \cdot 8$ & $73 \cdot 4$ & 103 \\
40 & $92 \cdot 8$ & $93 \cdot 8$ & 102 \\
40 & $92 \cdot 8$ & $92 \cdot 4$ & 99 \\
$40^{*}$ & $40 \cdot 0$ & $38 \cdot 6$ & 97 \\
$40^{*}$ & $40 \cdot 0$ & $41 \cdot 7$ & 104 \\
\multicolumn{4}{r}{ * Added to 3 ml. of saline solution. }
\end{tabular}

deproteinization was not satisfactory because creatine was trapped in the large amount of protein. Creatine and creatinine migrated toward the cathode in a multiple-cell electrodialysis unit, but quantitative separation from the plasma compartment was not complete after $8 \mathrm{hr}$. No interconversion of creatine and creatinine occurs on the resins.

$p$-Chloromercuribenzoic acid was added to duplicate tubes of plasma samples without effect on the value of creatine. It was observed, however, that $p$-chloromercuribenzoic acid increased the observed value of creatine in red-cell haemolysates, and the inhibition of the diacetyl reaction in wholeblood filtrates (Ennor \& Stocken, 1948) may be due to substances present in the red cells.

By the described method, recoveries ranging from 96.1 to $104.0 \%$ were obtained from addition of creatine to plasma (Table 3). In eight healthy adult males, the plasma creatine was $2.9 \pm 1.5 \mathrm{mg}$./ ml.

\section{DISCUSSION}

Before the Barritt (1936) modification of the VogesProskauer diacetyl reaction, creatine was measured by the Jaffe reaction after conversion into creatinine by heating with acid. The Jaffe reaction itself is non-specific (Hunter, 1928), and considerable controversy has existed about the absolute value of creatinine so measured. Two methods for the accurate determination of creatinine have come into general use: the enzymic method of Miller \& Dubos (1937) and the adsorption of creatinine on Lloyd's reagent and subsequent determination by the Jaffe reaction (Borsook, 1935). Owen et al. (1954) compared the methods critically and concluded that the most convenient compromise suitable for routine use was the latter method. The measurement of creatine by the difference of creatinine values before and after heating with acid is subject to gross errors. Heat and acid may give rise to other Jaffepositive chromogens; guanidinoacetic acid, for example, is converted into the Jaffe-positive chromogen glycocyamidine by heat and acid (Hunter, 1928). When a small amount of creatine is present with large amounts of creatinine, as in urine, there are the difficulties of accurately measuring a small difference. The use of the Barritt (1936) modification of the diacetyl reaction for the routine analysis of biological fluids has been limited by the presence of inhibitors which interfere with the reaction (Eggleton et al. 1943; Ennor \& Stocken, $1948,1953)$. We have overcome this difficulty by the prior separation of creatine by ion-exchange chromatography.

Arginine, guanidine and guanidinoacetic acid react with diacetyl to give a colour about one-ninth of the intensity of an equivalent amount of creatine. Creatinine and creatine phosphate do not react under the conditions described (Eggleton et al. 1943). Of the guanidinium compounds which react in the diacetyl test, only arginine and guanidinoacetic acid are likely to be present in urine and plasma in amounts large enough to cause interference (Van Pilsum, Martin, Kito \& Hess, 1956). Arginine is completely removed and guanidinoacetic acid is removed to a considerable extent by the ion-exchange resins. Thus the creatine values obtained by this method are high by about $10 \%$. For very accurate determinations, the amount of guanidinoacetic acid present may be determined by the Sakaguchi reaction and the creatine values corrected. In creatinuria, the error produced by the presence of guanidinoacetic acid is negligible.

Creatinine is slowly converted into creatine in the alkaline condition under which the diacetyl-colour reaction is performed. Prior removal of the creatinine by ion-exchange chromatography eliminates the slow increase in creatine and in colour with time.

\section{SUMMARY}

1. A method is described for the determination of creatine in biological fluids by the colour reaction with diacetyl in the presence of $\alpha$-naphthol. The creatine is partly separated before the colour reaction by ion-exchange chromatography.

2. Ion-exchange chromatography removes inhibitors of the diacetyl reaction, arginine (which gives a coloured product with diacetyl) and creatinine.

3. The separation and detection of creatine, creatinine and related compounds by paper chromatography is described.

\section{REFERENCES}

Barritt, M. M. (1936). J. Path. Bact. 42, 441.

Berry, H. K., Sutton, H. E., Cain, L. \& Berry, J. S. (1951). Biochemical Institute Studies, vol. 4. Austin, Texas: University of Texas Press. 
Borsook, H. (1935). J. biol. Chem. 110, 481.

Eggleton, P., Elsden, S. R. \& Gough, N. (1943). Biochem. J. 37, 526.

Ennor, A. H. \& Stocken, L. A. (1948). Biochem. J. 42, 557.

Ennor, A. H. \& Stocken, L. A. (1953). Biochem. J. 55, 310.

Hunter, A. (1928). Creatine and Creatinine. London: Longmans Green and Co.
Miller, B. F. \& Dubos, R. (1937). J. biol. Chem. 121, 457.

Owen, J. A., Iggo, B., Scandrett, F. J. \& Stewart, C. P. (1954). Biochem. J. 58, 426.

Van Pilsum, J. F., Martin, R. P., Kito, E. \& Hess, J. (1956). J. biol. Chem. 222, 225.

Yanofsky, C., Wasserman, E. \& Bonner, D. M. (1950). Science, 111, 61.

\title{
Hormones and Liver Gytoplasm
}

\section{RIBONUCLEOTIDES, RIBONUCLEIC ACID SYNTHESIS AND PROTEIN SYNTHESIS AFTER ADRENALECTOMY*}

\author{
By E. REID AND BARBARA M. STEVENS $\dagger$ \\ Chester Beatty Research Institute, Institute of Cancer Research: Royal Cancer Hospital, London, S.W. 3
}

(Received 5 March 1957)

After adrenalectomy, the supernatant fraction obtained from rat liver by differential centrifuging shows increases in the amount of ribonucleic acid (RNA) (Reid, 1955) and in the incorporation of injected $\left[6-{ }^{14} \mathrm{C}\right]$ orotic acid into the RNA (Reid, O'Neal, Stevens \& Burnop, 1956). On the other hand, the microsomal fraction shows a decreased incorporation of orotic acid. This decrease is in accordance with the postulated role of microsomal RNA in protein synthesis, the rate of which as judged by the incorporation of injected $\mathrm{DL}-\left[1-{ }^{14} \mathrm{C}\right]$ leucine appears to be slightly diminished after adrenalectomy (Reid et al. 1956). No attempt was made in these studies to ascertain whether adrenalectomy affected the precursor 'pool' or the time course of incorporation. It was not therefore conclusively proved that the increase in the amount of RNA in the supernatant fraction is due to increased synthesis as distinct from decreased catabolism or that this RNA has some function unconnected with protein synthesis.

A closer study has now been made in an endeavour to clarify not only these aspects but also the origin, the fate and the possible metabolic diversity of the RNA of the supernatant fraction.

Liver ribonucleotides have also been investigated, to ascertain whether adrenalectomy affects the ribonucleotide pool and, in particular, the pool of the uridine phosphates into which injected orotic acid is rapidly converted (Hurlbert \& Potter, 1952, 1954; Schmitz, Hurlbert \& Potter, 1954).

Another aspect which has now been studied, as briefly reported elsewhere (Reid \& Stevens, 1956), is the sequence after adrenalectomy of the various changes in the metabolism of RNA and of protein.

* Part 3: Stevens \& Reid (1956).

$\dagger$ Royal Marsden Hospital Gordon Jacobs Fellow.

\section{EXPERIMENTAL}

Experimental procedures are described in detail only where these differ from those employed in Part 1 (Reid et al. 1956). As previously, the animals were male rats, wt. about $250 \mathrm{~g}$., which had been fed on a protein-rich diet in restricted amount and which were fasted overnight before autopsy. Adrenalectomized rats were maintained with saline.

\section{Chromatography of ribonucleotides}

Each experiment was performed with pooled liver samples (total 10-11 g.) from two rats. In the later experiments, as indicated in Table 1, the rats were killed by decapitation, and the liver was ground to a powder in the frozen state (liquid nitrogen) before extraction with perchloric acid solution, as described by Hurlbert \& Potter (1954) and Hurlbert, Schmitz, Brumm \& Potter (1954) but without perfusion of the liver.

Analysis of the neutralized extracts was performed by anion-exchange chromatography on Dowex 1 (formate) columns, by a gradient-elution procedure with three changes of solvent as described by Hurlbert et al. (1954). The $\mathrm{pH}$ of the solvents was not adjusted. The mixing flask (containing water initially) was of $500 \mathrm{ml}$. volume, and the resin column $15 \mathrm{~cm} . \times 0.72 \mathrm{~cm} .{ }^{2}$ in size; with a longer column $(20 \mathrm{~cm}$.) the resolution was little improved. The effluent was collected in $5 \mathrm{ml}$. portions (about 300 in each run) which were examined spectrophotometrically at $260 \mathrm{~m} \mu$ and, in some instances, at $275 \mathrm{~m} \mu$. In general, each run was carried out for 3 days without interruption of the flow, the elution pattern being distorted after any interruption. In experiments with radioactive material, performed in a distant laboratory with consequent difficulty in supervision, the runs were shortened by using only two solvents ( $4 \mathrm{~N}$-formic acid followed by $4 \mathrm{~N}$-formic acid containing M-ammonium formate), with resulting loss of resolution in the later stages (Expt. 2 of Table 1).

Some of the fractions thus obtained were rechromatographed after removal of water and formic acid by freezedrying; if the fraction also contained ammonium formate, this was removed by the cautious use of an infrared lamp in 